\title{
Uwzględnienie zagadnień geopolityki i geostrategii w analizach strategicznych
}

\author{
Dr hab. Zbigniew Matyjas, prof. UŁ iD \\ Uniwersytet Łódzki, Wydział Zarządzania \\ Katedra Strategii i Zarządzania Wartością Przedsiębiorstwa
}

\section{Wprowadzenie}

Ostatnie kilkadziesiąt lat to okres niekwestionowanego rozwoju polskiej gospodarki. Widoczne jest to zarówno w tzw. twardych wskaźnikach makroekonomicznych (typu wzrost PKB, poziom bezrobocia, stopa inflacji czy też stopy procentowe), jak i w stopniowo rosnącej konkurencyjności polskich przedsiębiorstw. Jednocześnie sukcesywnie rośnie zaawansowanie technologiczne gospodarki i, co za tym idzie, polskich przedsiębiorstw. Rozwój polskiej gospodarki prowadzi do pojawiania się coraz śmielszych pomysłów na dalszy rozwój gospodarczy kraju, co wzbudza szerokie zainteresowanie mediów, opinii publicznej, środowisk opiniotwórczych oraz, co zrozumiałe, świata akademickiego.

Od dłuższego czasu w mediach i prasie specjalistycznej pojawiają się koncepcje wyjścia z tzw. pułapki średniego dochodu, z reguły oparte na wykorzystaniu wzrostu innowacyjności polskiej gospodarki. W znacznej mierze temu podporządkowana została wydana w 2017 roku Strategia na Rzecz Odpowiedzialnego Rozwoju$^{1}$ (SOR) - powszechnie nazywana planem Morawieckiego. Lista projektów strategicznych wymienionych w planie jest bardzo szeroka i nadzwyczaj ambitna, koncentracja zadań przyporządkowana została realizacji trzech celów szczegółowych (wzrost gospodarczy, oparty m.in. na wiedzy, rozwoju społecznie wrażliwym i zrównoważonym terytorialnie oraz mechanizmach budowania skutecznego państwa). Lista projektów strategicznych jest długa, znaleźć na niej można inicjatywy zmierzające do znacznego unowocześnienia polskiej gospodarki (np. zmiany w polityce przemysłowej, transformację w kierunku gospodarki niskoemisyjnej, „Przemysł 4.0”, Konstytucję Biznesu, doktoraty wdrożeniowe, zmiany

1 Strategia na Rzecz Odpowiedzialnego Rozwoju do roku 2020 (z perspektywa do 2030 r.), Ministerstwo Rozwoju, Warszawa 2017. 
polityki inwestycyjnej państwa czy też próbę wsparcia ekspansji zagranicznej), przy jednoczesnym zachowaniu spójności społecznej (m.in. polityka prorodzinna, wsparcie dla osób starszych oraz niesamodzielnych) i terytorialnej (np. pakt dla obszarów wiejskich, Program dla Śląska, pakiet dla średnich miast). Realizacji SOR podporządkowane zostały również kluczowe cele inwestycyjne kraju, między innymi w zakresie kapitału ludzkiego, transportu, energii czy bezpieczeństwa narodowego.

Strategia na Rzecz Odpowiedzialnego Rozwoju jest wdrażana już właściwie od czterech lat i zadaniem niniejszego opracowania nie jest ocena skuteczności jej zaprojektowania oraz implementacji, niemniej jednak uwagę zwraca przynajmniej jeden charakterystyczny czynnik. Otóż sceptyczne wobec planu (aczkolwiek z pewnością nie wobec rozwiązania problemu tzw. średniego dochodu) ośrodki medialne (oraz część prasy specjalistycznej) podważają możliwości realizacji bardziej ambitnych projektów inwestycyjnych i rozwojowych kraju. Dotyczy to w szczególności jednego z najbardziej ambitnych projektów (formalnie nieujętego w ramach SOR, jednak znakomicie wpisującego się w jego ramy) w postaci budowy Centralnego Portu Komunikacyjnego (CPK, formalnie Port Solidarność - Centralny Port Komunikacyjny Rzeczypospolitej Polskiej). Zgodnie z koncepcją rządową ma to być innowacyjny węzeł transportowy, ulokowany pomiędzy Warszawą a Łodzią (około $40 \mathrm{~km}$ na zachód od Warszawy i $80 \mathrm{~km}$ na wschód od Łodzi) w bezpośrednim sąsiedztwie autostrady A2, składający się z dwóch komponentów: lotniczego (z docelową możliwością obsługi $100 \mathrm{mln}$ pasażerów rocznie) oraz kolejowego (rozbudowanie w układzie gwiaździstym linii kolejowych łączących główne aglomeracje z CPK). Również inne ambitne projekty rozwojowe gospodarki krajowej, do których zaliczyć można między innymi rozwój energetyki jądrowej, niektórych korytarzy transportowych (kołowych, jak Via Carpatia, bądź kolejowych, jak Kolej Dużych Prędkości - Linia Y), sektora zbrojeniowego czy też przekop Mierzei Wiślanej, budzą, przynajmniej częściowo, sceptycyzm.

Skala potencjalnych nakładów związanych z dalszym unowocześnianiem polskiej gospodarki jest ogromna. Szacunki strony rządowej wspominają o kwocie przekraczającej 2 biliony złotych (2 tysiące miliardów), z czego znacząca część powinna być obsłużona przez podmioty krajowe. Stąd już obecnie widać duże zainteresowanie biznesu nowymi strategicznymi inwestycjami, co będzie powodowało konieczność analizowania wspomnianych wyżej (i wielu innych) nowych projektów rozwojowych nie tylko pod kątem makroekonomicznym, lecz również biznesowym.

Tymczasem do tej pory dyskurs naukowy oparty na solidnych podstawach analitycznych w tym zakresie nie jest duży. Bywa wręcz, iż powtarzane są stereotypowe opinie opierane na budzących wątpliwości źródłach, których motywy są niejasne. 
Niejednokrotnie są one mocno sceptyczne, a sceptycyzm ten nie jest we właściwy sposób poddany rygorom analitycznym wymaganym do prowadzenia dyskursu naukowego w obszarze nauk o zarządzaniu i jakości. W istniejących rozważaniach i dyskusjach prowadzonych na tym gruncie wyraźnie brakuje uwzględnienia istotnego wymiaru pozwalającego na uchwycenie pełniejszego i bardziej spójnego obrazu sytuacji dotyczącej dalszego kierunku rozwoju Polski, mianowicie zagadnień geopolitycznych.

Należy przy tym zauważyć, iż w obszarze nauk o zarządzaniu, w tym w szczególności w ramach zarządzania strategicznego, wykształcono mechanizmy analizy i oceny oddziaływania zjawisk natury politycznej na funkcjonowanie biznesu. Jest to szczególnie widoczne w ramach analiz otoczenia makro, niemniej jednak należy wskazać, iż analizy te w zasadzie nie dotyczą aspektów geopolitycznych, wpływających w znacznym stopniu na kształtowanie rzeczywistości biznesowej, w której funkcjonują przedsiębiorstwa, i na bazie których podejmowane są decyzje gospodarcze.

Stąd, mając powyższe na uwadze, można stwierdzić występowanie luki badawczej w postaci niedostatecznego uwzględnienia aspektów geopolityki i geostrategii w prowadzeniu analiz strategicznych (rozumianych biznesowo). Niemniej jednak, biorąc pod uwagę charakter i objętość niniejszego opracowania, nie będzie możliwe przeprowadzenie kompleksowych rozważań w tym zakresie, wobec czego celem rozdziału jest zarysowanie znaczenia elementów geopolityki i geostrategii dla prowadzenia analiz strategicznych. Punktem wyjścia będzie skrótowe wyjaśnienie obu pojęć i przedstawienie ich znaczenia dla sytuacji, w jakiej obecnie znajduje się polska gospodarka. Następnie, po krótkiej typologii metod analiz strategicznych autor podejmie wstępną próbę poszukiwania mechanizmów uwzględnienia współczesnych zagadnień geopolitycznych w ramach wybranych analiz strategicznych. Jak zostało wyżej zaznaczone, ograniczenia związane $\mathrm{z}$ charakterem rozdziału powodują konieczność potraktowania opracowania wyłącznie jako szkicowego, stanowiącego wprowadzenie do dalszych prac w tym zakresie, w tym prac o charakterze analitycznym oraz empirycznym.

\section{Geopolityka i geostrategia - rys znaczeniowy pojęć}

Z politycznego, zbieżnego z ekonomicznym i biznesowym, punktu widzenia ważne jest rozróżnienie trzech istotnych pojęć ${ }^{2}$. Pierwszym z nich jest geografia - w sumie tożsama z tradycyjnym, szkolnym pojmowaniem geologicznych uwarunkowań

2 Z. Brzeziński, Wielka szachownica. Gtówne cele polityki amerykańskiej, Świat Książki, Warszawa 1998. 
każdego państwa. Jest ona zasadniczo niezmienna w czasie, aczkolwiek wpływ i znaczenie określonego miejsca w przestrzeni geograficznej może się z czasem zmieniać. Bartosiak stwierdza, iż „geografia determinuje dystrybucję władzy i daje przewagi określonym miejscom i regionom w stosunku do innych"3. Może to być związane z uwarunkowaniami klimatycznymi, dostępnością surowców naturalnych, dostępem do morza, rzekami, liniami brzegowymi i innymi czynnikami natury geograficznej, tworzącymi swego rodzaju brzegowe warunki przewagi konkurencyjnej państwa.

Kolejnym pojęciem jest geopolityka - rozumiana z reguły jako celowa działalność ludzka (w wymiarze państwowym), determinująca wykorzystanie znaczenia czynników geograficznych danego kraju do osiągania przez niego określonych rezultatów politycznych (rozumianych tak w kategoriach wojskowych, jak i ekonomicznych). Jednymi z najważniejszych czynników kształtujących potencjał geopolityczny danego państwa są kontrolowane przez nie linie komunikacyjne, mające przemożny wpływ na sytuację ekonomiczną poszczególnych państw.

Trzecim ze wskazanych powyżej pojęć jest geostrategia, przez którą rozumieć należy sposób organizacji podejmowanych przez dane państwo działań w celu realizacji określonych zamierzeń geopolitycznych. Pojęcie to jest czasowo najwęższe w stosunku do dwóch pozostałych, zmiany działań w obszarze geostrategii mogą być bardzo szybkie, podyktowane zmieniającymi się uwarunkowaniami zewnętrznymi. Obecnie do najbardziej charakterystycznych decyzji o charakterze geostrategicznym zaliczyć należy dwa działania realizowane przez najpotężniejsze światowe mocarstwa ${ }^{4}$ : USA - tzw. Pacific Pivot oraz Chiny - najistotniejszą zmianą jest zapowiedź budowy tzw. Nowego Jedwabnego Szlaku - właściwie Inicjatywa Pasa i Szlaku (The Bell and Road Initiative). Działania te mają potencjalnie dalekosiężny wpływ na przyszłe funkcjonowanie polskiej gospodarki oraz perspektywy rozwojowe wielu polskich przedsiębiorstw.

\section{Morze kontra Ląd}

Doktryny geopolityczne, dobrze znane zwłaszcza w świecie anglosaskim, w warunkach krajowych rozpowszechniają się z pewnym trudem. Tymczasem ich najważniejsze przesłanki mają kapitalne znaczenie dla dalszego rozwoju gospodarczego (i nie tylko) Polski, co wynika między innymi z uwarunkowań geograficznego położenia kraju. Często przyjmuje się, iż znajduje się ona w tzw. strefie zgniotu, tj.

3 J. Bartosiak, Rzeczpospolita między lq̨dem a morzem. O wojnie i pokoju, Zona Zero, Warszawa 2018, s. 34.

4 Więcej: J. Bartosiak, Przeszłość jest prologiem, Zona Zero, Warszawa 2019. 
strefie pomiędzy oddziaływaniami dwóch najpotężniejszych w XX wieku mocarstw europejskich - Niemiec i Rosji. Niemniej jednak obecnie zarysowuje się możliwość zmiany tej sytuacji, z uwagi na znaczące przesunięcie światowego centrum ekonomicznego i biznesowego na Daleki Wschód, a przede wszystkim z uwagi na rosnącą potęgę Chin. To już obecnie prowadzi do odbierania geograficznego położenia Polski jako miejsca sworzniowego (piwotalnego) z powodu zdolności oddziaływania na styku dwóch stref wpływów geopolitycznych - lądowej i morskiej.

Rozwój geopolityki i kluczowe koncepcje w tym zakresie doprowadziły do zrozumienia podstawowych różnic pomiędzy sposobami funkcjonowania i osiągania supremacji przez potęgi morskie i kontynentalne (lądowe). Jednym z pierwszych autorów, który przedstawił spójną koncepcję w tym zakresie, był Mackinder - twórca koncepcji Heartlandu ${ }^{5}$. Według niego strategiczną przewagę osiągnie państwo, które zawładnie tzw. Wyspą Świata, z grubsza pokrywającą się z obszarem środkowej Azji, stanowiącą, zdaniem Mackindera, naturalną twierdzę lądową, bardzo trudną do zdobycia w wyniku wojen czy podbojów. Chociaż w ramach tej koncepcji Heartland jest uboższy ekonomicznie od państw morskich, jednak pozwala oddziaływać na szlaki handlowe z głębi stref lądowych niekontrolowanych przez Morze.

Przeciwstawną koncepcję Rimlandu 6 zaproponował Spykman, który uważał, iż przewagę mają potęgi morskie, kontrolujące najważniejsze morskie szlaki handlowe. Sam Rimland zaś ograniczony jest do stosunkowo niedużej strefy przybrzeżnej, najczęściej rozumianej jako strefa handlu atlantyckiego, obecnie również pacyficznego. Kontrola strefy przybrzeżnej odbywa się dzięki znaczącej przewadze floty mocarstwa morskiego.

Obie te teorie wywarły ogromny wpływ na sposób myślenia politycznego, militarnego i ekonomicznego elit państw anglosaskich. Ich analogiczne (czasami nieco zmienione) wersje były również wykorzystywane przez inne mocarstwa (np. Niemcy, Rosję, Chiny). Co ciekawe, położenie geograficzne Polski dla obu tych koncepcji jest bardzo istotne, gdyż znajduje się ona na styku oddziaływania Heartlandu z Rimlandem, stąd między innymi historyczne problemy wynikające z niego z XX wieku. Niemniej jednak położenie takie ma również potencjalne zalety, zwłaszcza uwzględniając zmiany geopolityczne zachodzące w głównych światowych potęgach.

5 H.J. Mackinder, The Geographical Pivot of History, „The Geographical Journal” 1904, vol. 23, no. 4, s. 421-437.

6 P. Eberhardt, Koncepcja Rimlandu Nicholasa Spykmana i jej konsekwencje geopolityczne, „Przegląd Geograficzny” 2014, t. 86, nr 2, s. 261-280. 


\section{Obecne zmiany geopolityczne na świecie}

W ostatnich latach znaczną aktywność ekonomiczną przejawiają Chiny, które poszukują dalszych metod rozwoju gospodarczego przy utrzymaniu (względnie nieznacznym spowolnieniu) obecnego tempa rozwoju. Nie jest to zadanie proste, zważywszy na skalę tej gospodarki - przestawienie motoru wzrostu chińskiego na innowacyjność zapewne będzie również dotknięte pułapką średniego dochodu.

Jednym z najambitniejszych projektów strategicznych ostatnich lat (a może wręcz stulecia) wydaje się Nowy Jedwabny Szlak. Należy zauważyć, iż nie jest to wyłącznie duży projekt infrastrukturalny - inicjatywę tę należy traktować jako przełomowy mechanizm pozwalający na uzyskanie przewagi strategicznej przez Ląd względem Morza. Proponowane trasy szlaku znajdują się w głębi euroazjatyckich lądów, z daleka od dotychczas dominującej komunikacji morskiej. W przypadku sukcesu projektu (a można to zakładać z dość dużym prawdopodobieństwem) nastąpi znaczące ożywienie gospodarcze wielu krajów leżących wzdłuż trasy, co stanowi dla nich dodatkową zachętę. Inicjatywa ta może mieć również w przyszłości kapitalne znaczenie dla rozwoju gospodarczego Polski, z uwagi na - tym razem bardzo korzystne - położenie geograficzne.

Projekt ten wzbudza zrozumiałe zainteresowanie wielu państw, które mogą potencjalnie na nim skorzystać. Budzi jednak również niechęć dotychczasowego imperium - USA. Stany Zjednoczone od kilku już lat realizują strategię Pacific Pivot ${ }^{7}$ (Zwrot na Pacyfik), wychodząc z przekonania, iż światowy handel przeorientował się w ostatnich dwóch dekadach z dominacji atlantyckiej na pacyficzną. Jednocześnie pojawił się gracz formatu światowego w postaci Chin, który swoimi działaniami zagraża podstawom tzw. amerykańskiego ładu. Oznacza to możliwość stopniowej marginalizacji dotychczas dominujących gospodarczo, obok Amerykanów, mocarstw europejskich.

Wspomniane zostały dwa, zapewne najistotniejsze obecnie działania geopolityczne, co oczywiście nie zamyka listy. Należy bowiem mieć na uwadze fakt, iż interesy gospodarcze danych krajów są przez nie realizowane w różnoraki sposób, z wykorzystaniem szerokiego arsenału dostępnych narzędzi (takich jak chociażby teoria gier ${ }^{8}$ ), często w sposób cyniczny i bezwzględny ${ }^{9}$, choćby kosztem przeciwnika ${ }^{10}$. A to oznacza, iż właściwe zrozumienie szerokich uwarunkowań

7 Więcej: J. Bartosiak, Pacyfik i Eurazja. O wojnie, Zona Zero, Warszawa 2018.

8 P. D. Straffin, Teoria gier, Wydawnictwo Naukowe Scholar, Warszawa 2004.

9 S. Tzu, S. Pin, Sztuka wojny, Wydawnictwo Helion, Gliwice 2004.

10 Więcej: S. Hongbing, Wojna o pieniq̨dz. Prawdziwe źródła kryzysów finansowych, Wydawnictwo Wektory, Wrocław, 2010; S. Hongbing, Wojna o pieniq̨dz 2. Świat władzy pieniqdza, 
geopolitycznych powinno odbywać się nie tylko na poziomie ośrodka władzy państwowej, lecz również przedsiębiorstw, zwłaszcza zainteresowanych ekspansją międzynarodową. Stąd właściwym podejściem wydaje się próba implementacji perspektywy geopolitycznej do wybranych metod analizy strategicznej.

\section{Kategoryzacja analiz strategicznych - zróżnicowanie z uwagi na poziom prowadzonej analizy}

Typologia analiz strategicznych z reguły prowadzi do wyodrębnienia zróżnicowanych poziomów prowadzonych analiz ${ }^{11}$. Z uwagi na charakter opracowania przedstawione zostaną wyłącznie dwie typologie prowadzonych analiz strategicznych.

Gierszewska i Romanowska zaproponowały klasyczny i przyjęty w warunkach krajowych model podziału na12:

- analizy makrootoczenia - gdzie obok wyodrębnienia poszczególnych segmentów otoczenia wskazuje się analizę makrootoczenia oraz metody scenariuszowe;

- analizy otoczenia konkurencyjnego - gdzie obok klasycznych metod w postaci analizy pięciu sił oraz analizy grup strategicznych ${ }^{13}$ (zwanej również mapą grup strategicznych ${ }^{14}$ ) znajdują się też między innymi analiza potencjału globalizacyjnego sektora oraz krzywa doświadczeń;

- analizy potencjału strategicznego przedsiębiorstwa - gdzie tradycyjne techniki w postaci analizy kluczowych czynników sukcesu, metod portfelowych oraz analizy łańcucha wartości uzupełnione zostały między innymi analizą zasobów przedsiębiorstwa i bilansem strategicznym przedsiębiorstwa;

Wydawnictwo Wektory, Wrocław 2011; S. Hongbing, Wojna o pieniq̨dz 3. Epoka walczqcych królestw, Wydawnictwo Wektory, Wrocław 2016; S. Hongbing, Wojna o pieniq̨dz 4. Cisza przed burzq, Wydawnictwo Wektory, Wrocław 2018.

11 Z. Matyjas, Tendencje rozwojowe zarzq̨dzania strategicznego w świetle badań bibliometrycznych, „Marketing i Rynek” 2015, nr 9, s. 363-377.

12 G. Gierszewska, M. Romanowska, Analiza strategiczna przedsiębiorstwa, Polskie Wydawnictwo Ekonomiczne, Warszawa 2017.

13 Więcej: Z. Matyjas, Koncepcja grup strategicznych - w stronę dynamicznych modeli konkurowania (przegląd badań światowych), „Acta Universitatis Lodziensis. Folia Oeconomica” 2011, nr 258, s. 77-93.

14 J. Jeżak, Z. Matyjas, Mapa grup strategicznych elementem analizy konkurencji w sektorze, „Przegląd Organizacji” 2001, nr 9, s. 7-12. 
- ocenę pozycji strategicznej przedsiębiorstwa15 - poprzez analizy SPACE i SWOT ${ }^{16}$.

Nieco inną klasyfikację proponują Fleisher i Bensoussan ${ }^{17}$. Według nich podział koncentruje się wokół:

- technik analizy strategicznej - między innymi podejścia portfelowego, analiz sektorowych i grup strategicznych;

- technik analizy klientów i konkurencji - na przykład analizy martwych pól, analizy konkurentów, analizy segmentacji, analizy zasobów;

- technik analizy otoczenia - między innymi analizy STEEP (odmiany analizy PEST), analizy scenariuszowej, analizy interesariuszy;

- technik analizy ewolucyjnej - typu analiza krzywej doświadczenia, analiza patentów, analiza krzywej S;

- technik analizy finansowej - obok analiz wskaźnikowych, programowania funduszy strategicznych i analizy zrównoważonej stopy wzrostu.

\section{Mechanizmy uwzględnienia zakresu geopolityki i geostrategii w analizach strategicznych}

Mając na uwadze charakter i ramy bieżącego opracowania, można wyłącznie skrótowo i poglądowo przedstawić sposoby uwzględnienia problematyki geopolityki (oraz geostrategii) w poszczególnych analizach strategicznych. Co więcej, będzie to przeprowadzone wyłącznie w postaci koncepcyjnej, wskazując na kluczowe problemy, które powinny być, zdaniem autora, uwzględnione w prowadzonych analizach strategicznych. Dalsze rozważania prowadzone będą zgodnie z wyżej przedstawioną typologią podziału analiz strategicznych na trzy główne obszary - analizy makro, analizy otoczenia konkurencyjnego oraz analizy potencjału wewnętrznego.

Na poziomie analizowania makrootoczenia perspektywa geopolityki i geostrategii powinna odgrywać istotną rolę. Należy mieć na uwadze, iż od pewnego czasu postulowane jest rozszerzenie tego typu analiz (z natury uwzględniających aspekt polityczny) o skanowanie otoczenie międzynarodowego czy wręcz globalnego.

15 Celem uzupełnienia: Adam Stabryła wyróżnia trzy grupy metod poprzez połączenie dwóch ostatnich do postaci analizy strategicznej firmy - por. A. Stabryła, Zarzq̨dzanie strategiczne w teorii i praktyce firmy, Wydawnictwo Naukowe PWN, Warszawa - Kraków 2000.

16 Rozszerzenie analizy SWOT patrz: Z. Matyjas, Wzorce konkurowania przedsiębiorstw w sektorach - podejście dynamiczne, Wydawnictwo Uniwersytetu Łódzkiego, Łódź 2013.

17 C.S. Fleisher, B.E. Bensoussan, Strategic and Competitive Analysis. Methods and Techniques for Analyzing Business Competition, Prentice Hall, Upper Saddle River 2003. 
To już na wstępie narzuca pewien sposób myślenia, który należy tylko uzupełnić o aspekt jasno sprecyzowanej geopolityki głównych graczy, rozumianych najczęściej jako konkurenci. Na tym szczeblu analitycznym widać w pełni potencjalne konflikty interesów, które de facto są często rozbieżne. Przykładowo: zarówno Polska, jak i Czechy aspirują do roli punktu węzłowego dla jednej z linii Nowego Jedwabnego Szlaku, konkurentem dla obu państw będą natomiast z pewnością Niemcy - to wszystko powoduje rozbieżności geostrategiczne, co dalej przekłada się na odmienną sytuację firm zainteresowanych udziałem w tym projekcie. Pełna analiza sytuacji możliwa jest dopiero po uwzględnieniu czynników natury geopolitycznej, co więcej - w tym przypadku możliwe jest wdrożenie pełnego podejścia scenariuszowego ${ }^{18}$, pozwalającego na precyzyjne wypracowanie spójnych wariantów działania przedsiębiorstwa (czy też ośrodka władzy państwowej bądź samorządowej). Pozwala to na minimalizację kosztownych błędów i pomyłek już na etapie analitycznym.

Poziom otoczenia konkurencyjnego z pewnością umożliwia również wykorzystanie zrozumienia uwarunkowań geopolitycznych i geostrategicznych. Ostatecznie to na tym poziomie najczęściej skoncentrowana jest polityka poszczególnych państw, które relatywnie rzadziej dokonują realnych działań na poziomie przedsiębiorstw. Jednocześnie ten poziom analiz jest od wielu lat bardzo dobrze rozpoznany, a punktem wyjścia dla wielu z nich były lata doświadczeń analitycznych i badawczych prowadzonych w ramach ekonomii sektorowej19 (Industrial Organization Economics), czego wyrazem była opracowana przez Portera analiza tzw. pięciu sił ${ }^{20}$. Uwzględnienie zagadnień natury geopolitycznej powinno być przede wszystkim dostosowane do kluczowych sektorów, będących przedmiotem strategicznego zainteresowania. Obecnie do sektorów takich z pewnością zaliczyć należy energetykę (w tym atomową), produkcję elektroniki dla potrzeb zapewnienia bezpieczeństwa kraju, rozwój korytarzy transportowych, sektor zbrojeniowy i inne strategicznie istotne dla rozwoju kraju sektory. Przy czym tutaj, w przeciwieństwie do analiz na poziomie makrootoczenia, implementacja zagadnień geopolitycznych wymaga uzupełnienia istniejących metod o perspektywę geopolityczną (np. w ramach pięciu sił). Przykładowo: analizując uwarunkowania konkurencyjności sektora energetycznego, nie sposób nie zauważyć geostrategii Niemiec (oraz Rosji) w postaci budowanego gazociągu Nord Stream II (i potencjalnych konsekwencji

18 K. van der Heijden, Planowanie scenariuszowe w zarzq̨dzaniu strategicznym, Dom Wydawniczy ABC, Kraków 2000.

19 Z. Matyjas, Ekonomika organizacji przemysłowej w zarządzaniu strategicznym, „Acta Universitatis Lodziensis. Folia Oeconomica" 2011, nr 261, s. 307-318.

20 M.E. Porter, Strategia konkurencji. Metody analizy sektorów i konkurentów, Polskie Wydawnictwo Ekonomiczne, Warszawa 1994. 
dla norwesko-duńsko-polskiego gazociągu Baltic Pipe). Uwzględniając promowany od wielu lat rozwój energetyki wiatrowej w Niemczech z dostępnością gazu pozwalającego na produkcję energii elektrycznej z wykorzystaniem turbin gazowych, widać konflikt interesów w stosunku do rozwoju polskiej energetyki. Dopiero uwzględnienie $\mathrm{w}$ analizie elementów $\mathrm{z}$ zakresu geopolityki pozwala na dostrzeżenie znacznie szerszej perspektywy. A to ponownie umożliwia uniknięcie ewentualnych błędów i kosztownych pomyłek już na etapie analitycznym.

$\mathrm{Z}$ pewnością trudniej jest natomiast zaimplementować perspektywę geopolityczną do analiz potencjału wewnętrznego przedsiębiorstwa. Wprawdzie elementem składowym analiz zasobowych (np. analizy VRIO ${ }^{21}$ ) jest analiza komparatywna w odniesieniu do kluczowych konkurentów, niemniej jednak - z wyłączeniem absolutnie kluczowych przedsiębiorstw zagranicznych - trudno jednoznacznie zidentyfikować elementy geopolityki danego państwa, odnoszące się wprost do konkretnej firmy. Pewne wnioski można wyciągnąć na podstawie podejmowanych przez firmy strategii, zwłaszcza kluczowych (takich jak np. strategia dywersyfikacji22), jednak dane na temat wpływu działań geopolitycznych na konkretne przedsiębiorstwa mogą być w zasadzie niedostępne. Stąd właściwymi podejściami wydają się analiza jakościowa czy też próba wykorzystania analogii. Dotyczy to jednak głównie największych podmiotów, które są strategicznie istotne dla funkcjonowania gospodarki analizowanego kraju.

\section{Podsumowanie}

Reasumując, należy stwierdzić, iż geopolityka i geostrategia mają wiele do zaoferowania z punktu widzenia uzupełnienia prowadzonych analiz strategicznych o rozważania w tych kierunkach. Należy przy tym pamiętać, iż w celu zwiększenia skuteczności prowadzonych analiz powinny one dotyczyć strategicznie istotnych sektorów (bądź przedsiębiorstw), gdyż z reguły to one są domeną ośrodków władzy rządowej prowadzącej działania o charakterze geopolitycznym.

Przeszło stuletnie doświadczenia rozwoju geopolityki wypracowały dwie teoretycznie sprzeczne (choć w praktyce w zasadzie uzupełniające się) doktryny: lądową (koncepcja Heartlandu) oraz morską (idea Rimlandu). Według obu tych koncepcji geograficzne położenie Polski jest piwotalne, z uwagi na fakt zamieszkiwania przez Polaków obszaru pomiędzy tymi dwoma sferami. W połączeniu z obecnie występującymi światowymi projektami rozwoju infrastrukturalnego

21 J.B. Barney, W.S. Hesterly, Strategic Management and Competitive Advantage. Concepts and Cases, Pearson, Upper Saddle River 2015.

22 Z. Matyjas, Strategie dywersyfikacji przedsiębiorstw - przegląd badań światowych, „Prace Naukowe Uniwersytetu Ekonomicznego we Wrocławiu” 2016, nr 420, s. 216-226. 
półkuli północnej, wraz z wyraźnie postępującym przesunięciem gospodarczego centrum świata na wschodnie wybrzeże Pacyfiku, będzie to z pewnością determinowało warunki rozwoju gospodarczego Polski na długie lata (niektórzy twierdzą, iż poprzednia tak znacząca zmiana zaszła w okresie odkryć geograficznych około pięciuset lat temu). Nową sytuację zauważył dotychczasowy hegemon - Stany Zjednoczone i jako reakcję zastosował Pacific Pivot.

Dotychczasowy słaby nacisk na uwzględnienie znaczenia zagadnień natury geopolitycznej w strategicznych analizach projektów rozwoju gospodarczego Polski może skutkować w dwojaki sposób. Po pierwsze może prowadzić do błędnych decyzji strategicznych podejmowanych przez przedsiębiorstwa w ramach prowadzonych przez nie strategii rozwoju. Po drugie zaś z pewnością prowadzić będzie do marginalizacji roli środowiska nauk o zarządzaniu i jakości w analizach ekonomicznych i finansowych, które z założenia pomijają ważkie aspekty podejmowanych decyzji, dostępne wyłącznie w ramach analiz strategicznych. A należy pamiętać, iż każda kolejna właściwie przeprowadzona analiza zmniejsza liczbę pomyłek (błędów) na etapie analitycznym - tym bardziej że właściwie przeprowadzone rozumowanie analityczne prowadzi do poprawnych wniosków. Udowodnił to między innymi Studnicki w swoim przerażająco skutecznym prognostyku efektu nadchodzącej wojny w roku $1939^{23}$.

Autor ma nadzieję, iż pomimo bardzo ograniczonych ram opracowania osiągnął jego założony cel w postaci zarysowania znaczenia elementów geopolityki i geostrategii dla prowadzenia analiz strategicznych. Należy mieć jednak świadomość, iż zagadnienie to jest bardzo złożone i wymaga dalszych prac koncepcyjnych, prowadzenia praktycznych analiz oraz (zapewne) badań empirycznych w celu wypracowania trwałego mechanizmu zaimplementowania kluczowych elementów geopolityki do prowadzenia analiz strategicznych.

\section{Bibliografia}

Barney J.B., Hesterly W.S., Strategic Management and Competitive Advantage. Concepts and Cases, Pearson, Upper Saddle River 2015.

Bartosiak J., Pacyfik i Eurazja. O wojnie, Zona Zero, Warszawa 2018.

Bartosiak J., Przeszłość jest prologiem, Zona Zero, Warszawa 2019.

Bartosiak J., Rzeczpospolita między lądem a morzem. O wojnie i pokoju, Zona Zero, Warszawa 2018.

Brzeziński Z., Wielka szachownica. Gtówne cele polityki amerykańskiej, Świat Książki, Warszawa 1998.

23 W. Studnicki, Wobec nadchodzącej Drugiej Wojny Światowej, Wydawnictwo Universitas, Kraków 2018 (przedruk oryginału z roku 1939). 
Eberhardt P., Koncepcja Rimlandu Nicholasa Spykmana i jej konsekwencje geopolityczne, „Przegląd Geograficzny" 2014, t. 86, nr 2, s. 261-280.

Fleisher C.S., Bensoussan B.E., Strategic and Competitive Analysis. Methods and Techniques for Analyzing Business Competition, Prentice Hall, Upper Saddle River 2003.

Gierszewska G., Romanowska M., Analiza strategiczna przedsiębiorstwa, Polskie Wydawnictwo Ekonomiczne, Warszawa 2017.

Heijden K. van der, Planowanie scenariuszowe w zarzq̨dzaniu strategicznym, Dom Wydawniczy ABC, Kraków 2000.

Hongbing S., Wojna o pieniq̨dz. Prawdziwe źródła kryzysów finansowych, Wydawnictwo Wektory, Wroctaw 2010.

Hongbing S., Wojna o pieniq̨dz 2. Świat władzy pieniądza, Wydawnictwo Wektory, Wrocław 2011.

Hongbing S., Wojna o pieniqdz 3. Epoka walczacych królestw, Wydawnictwo Wektory, Wrocław 2016.

Hongbing S., Wojna o pieniądz 4. Cisza przed burzq, Wydawnictwo Wektory, Wroctaw 2018.

Jeżak J., Matyjas Z., Mapa grup strategicznych elementem analizy konkurencji w sektorze, „Przegląd Organizacji” 2001, nr 9, s. 7-12.

Mackinder H.J., The Geographical Pivot of History, „The Geographical Journal” 1904, vol. 23, no. 4, s. 421-437.

Matyjas Z., Ekonomika organizacji przemysłowej w zarządzaniu strategicznym, „Acta Universitatis Lodziensis. Folia Oeconomica" 2011, nr 261, s. 307-318.

Matyjas Z., Koncepcja grup strategicznych - w stronę dynamicznych modeli konkurowania (przegląd badań światowych), „Acta Universitatis Lodziensis. Folia Oeconomica” 2011, nr 258, s. 77-93.

Matyjas Z., Strategie dywersyfikacji przedsiębiorstw - przeglą badań światowych, „Prace Naukowe Uniwersytetu Ekonomicznego we Wrocławiu" 2016, nr 420, s. 216-226.

Matyjas Z., Tendencje rozwojowe zarzq̨dzania strategicznego w świetle badań bibliometrycznych, „Marketing i Rynek” 2015, nr 9, s. 363-377.

Matyjas Z., Wzorce konkurowania przedsiębiorstw w sektorach - podejście dynamiczne, Wydawnictwo Uniwersytetu Łódzkiego, Łódź 2013.

Porter M.E., Strategia konkurencji. Metody analizy sektorów i konkurentów, Polskie Wydawnictwo Ekonomiczne, Warszawa 1994.

Stabryła A., Zarzq̨dzanie strategiczne w teorii i praktyce firmy, Wydawnictwo Naukowe PWN, Warszawa - Kraków 2000.

Straffin P. D., Teoria gier, Wydawnictwo Naukowe Scholar, Warszawa 2004.

Strategia na Rzecz Odpowiedzialnego Rozwoju do roku 2020 (z perspektywq do 2030 r.), Ministerstwo Rozwoju, Warszawa 2017.

Studnicki W., Wobec nadchodzqcej Drugiej Wojny Światowej, Wydawnictwo Universitas, Kraków 2018.

Tzu S., Pin S., Sztuka wojny, Wydawnictwo Helion, Gliwice 2004.

\section{Streszczenie}

Podstawowym celem opracowania jest próba odpowiedzi na pytanie, czy i w jaki sposób należy rozszerzyć klasyczne analizy strategiczne o zagadnienia geopolityki i geostrategii. Oba te terminy nabierają szczególnego znaczenia przy budowaniu ewentualnych analiz strategicznych dla najważniejszych projektów strategicznych, w tym w warunkach Polski. Dotyczy to przykładowo takich projektów jak Centralny Port Komunikacyjny, budowa elektrowni jądrowej czy też rozbudowa połączeń komunikacyjnych. Również zagadnienia związane z obronnością kraju, zarówno w aspekcie 
„twardym” (armia, sprzęt wojskowy), jak i „miękkim” (np. cyberobrona, rozwój polskiej mikroelektroniki), są w znacznym stopniu powiązane z zagadnieniami geopolityki i geostrategii. Tymczasem w warunkach krajowej literatury tematu problematyka ta nie była dotąd przedmiotem poważnego zainteresowania naukowego, stąd można zaobserwować wyraźną lukę badawczą w tym zakresie. Tematyka podjęta w rozdziale będzie miała za zadanie lukę tę zmniejszyć.

Słowa kluczowe: geopolityka, geostrategia, analizy strategiczne, poziomy analiz strategicznych

Strategic Analyses taking into account Geopolitics and Geostrategic Issues

\section{Abstract}

The main goal of the article is to answer the question whether and how to extend classic strategic analyzes to include geopolitics and geostrategy issues. Both of these terms are of particular importance when building possible strategic analyzes for major strategic projects in Poland. This applies, for example, to projects such as the Solidarity Transport Hub Poland, the construction of a nuclear power plant, or the development of transport connections. Also, issues related to national defense, both in the "hard" (army, military equipment) and "soft" aspects (e.g. cyber defense, development of Polish microelectronics), are largely linked to issues of geopolitics and geostrategy. Meanwhile, in the conditions of the domestic literature on the subject, these issues have not been the subject of serious scientific interest, hence a clear research gap in this respect can be observed. Therefore the task of the is to, at least partially, reduce this gap.

Keywords: geopolitics, geostrategy, strategic analyses, strategic analyses levels 